\title{
Land Tenure Systems and Agricultural Productivity in Gombe Nigeria
}

Daniel Ibrahim Dabara ${ }^{1 \star}$, Omotoso Kabir Lawal ${ }^{2}$, Augustina Chiwuzie ${ }^{1}$, Olusegun Joseph Omotehinshe ${ }^{3}$, and John Oyekunle Soladoye ${ }^{4}$

${ }^{1}$ Department of Estate Management, Federal Polytechnic Ede, Nigeria

${ }^{2}$ Department of Architectural Technology, Federal Polytechnic Ede, Nigeria

${ }^{3}$ Department of Building Technology, Federal Polytechnic Ede, Nigeria

${ }^{4}$ Department of Estate Management, Federal Polytechnic Offa, Nigeria

\section{Article Info}

\section{*Corresponding author:}

Daniel Ibrahim Dabara

Department of Estate Management

Federal Polytechnic Ede

Nigeria

Tel: +2348025615074

E-mail: danieldabara44@gmail.com

\section{Received: May 24, 2019}

Accepted: June 26, 2019

Published: July 6, 2019

Citation: Dabara DI, Lawal OK, Chiwuzie A, Omotehinshe OJ, Soladoye JO. Land Tenure Systems and Agricultural Productivity in Gombe Nigeria. Madridge J Agric Environ Sci. 2019; 2(1): 51-59.

doi: $10.18689 /$ mjaes- 1000110

Copyright: (c) 2019 The Author(s). This work is licensed under a Creative Commons Attribution 4.0 International License, which permits unrestricted use, distribution, and reproduction in any medium, provided the original work is properly cited.

Published by Madridge Publishers

\begin{abstract}
The purpose of this study is to examine the existing land tenure systems in Gombe state Nigeria with a view to determining its impact on agricultural productivity in the study area. The targeted population for the study comprised of 7,832 households in purposively selected agrarian settlements cutting across the 3 senatorial districts in Gombe state Nigeria. The population was stratified into three zones and two locations were selected from each zone. The sample size for the study comprised of 500 households in each of the study locations. Hence, 500 questionnaires were administered on the household heads of the 6 study locations making a total of 3,000 questionnaires (representing $38.3 \%$ of the targeted population). However only 2,223 (74.1\%) questionnaires were correctly filled and returned for analysis. The random sampling technique was adopted in the questionnaire administration. Descriptive statistical tools such as frequency counts, averages, weighted mean and percentages were used in analyzing the data obtained. The Relative Importance Index (RII) was used to identify and rank the variables. Inferential statistical tool such as multiple regressions were also used in analyzing the relationship between the criterion or dependent variable and the predictors or independent variables. The study revealed that customary land tenure system is the predominant type of tenure system (60.1\%) practiced in the study area. Similarly, agricultural productivity in the study area was shown to be impeded by land tenure insecurity (RII, 0.933963), political/bureaucratic bottlenecks in land rights acquisition for agricultural purposes (0.846154) and tenure rules such as stipulated in the Nigerian Land Use Act of 1978 (RII, 0.65596) among others. The study also showed a strong positive relationship of 0.809 between land tenure systems and agricultural productivity in the study area. The study concluded that for better agricultural productivity in the study area in particular and similar developing economies in general, farmers need to have secured land tenure as this encourages investments in the secured land which consequently improves agricultural productivity.
\end{abstract}

Keywords: Agrarian; Land tenure; Land reform; Tenure security.

\section{Introduction}

Land is arguably the most important natural resource to man. This is because it influences every aspect of man's basic need of food, clothing and shelter [1]. Lasun and Olufemi [2] asserted that no nation, city or rural area can survive as an entity without it. This implies that all citizens of a nation be it a banker, a teacher, a farmer, a politician, a military personnel, an industrialist, an estate surveyor among others all have a stake in the country's land and its utilization. For most people in developing countries such as Nigeria, Kenya, Ghana and Uganda, 
land is their primary means of livelihood as well as the major medium for investing and creation of wealth. Hence, land ownership as regulated by existing Land Tenure Systems (LTS) adopted by different countries is a key factor in the administration of any successful undertaking [3].

According to ECA report [4], the concept of 'tenure' is a social construct that defines the relationships between individuals and groups of individuals by which rights and obligations are defined with respect to control and use of land. Payne [5] defines land tenure as 'the mode by which land is held or owned, or the set of relationships among people concerning land or its product'. Land tenure plays an important role in the political, economic, social and legal structures of a group of people in particular and a nation in general. Land tenure relationships may be well defined and enforceable in a formal court of law or through customary structures in a community. Land tenure systems vary greatly among nations, the difference is more glaring especially between developing and developed nations. Some of the forms of land tenure systems adopted by countries across the globe include: customary, statutory, informal and religious forms of land tenure among others. It was observed that in Sub-Saharan Africa, the customary land tenure system is widely practiced [3]. This assertion is supported by Fisher [6] who further pointed out the major characteristics of customary tenure as land being owned by the whole community as opposed to an individual. Mabogunje [7] observed that in this type of system, the ownership of land is vested in a collective (whether a household, family, hamlet, lineage, clan or an entire community). Individuals in these group(s) can only enjoy the right of usage. The household head or the head of the 'collective' is vested with the power of custodianship of such land, which is to be held in trust for both present and future generations. In Sub Saharan Africa and especially Nigeria, such lands cannot be sold to strangers. It can only be transferred to members of the 'collective' base on certain criteria such as seniority, caste, gender etc. [8], hence, such members can use such land for their housing, agricultural or other needs.

Nigeria being a predominantly agricultural based economy has over 56.8 percent of its population engaged in agriculture $[9,10]$. This in turn accounts for about 40 percent of the Gross Domestic Product (GDP) in 1973 to 1974 (before the oil boom). Prior to 1970, the agricultural sector in Nigeria was the highest earner of foreign exchange. However, with the discovery of crude oil (petroleum) there was a swift paradigm shift from agriculture to crude oil for foreign exchange [11,12]. This has led to the agricultural sector experiencing serious decline as an earner of foreign exchange. Fabiyi [11] observed that out of the approximately 71.2 million hectares of cultivable land in Nigeria, only about 34 million hectares (about 48 percent) are currently being cultivated. The focus was shifted to crude oil at the detriment of the agricultural sector. Furthermore, Christian [8] observed that agricultural development in sub-Saharan Africa in terms of productivity and sustainability is hampered by lack of significant investment in the sector.

For agriculture to thrive in any economy, the existing land tenure systems must be favorably disposed to such development [13]. In Nigeria, the land tenure systems adopted for the Northern part of the country and that of the Southern part of the country were quite different. Similarly there were also variations observed between communities in the country. The major land tenure systems presently practiced in Nigeria includes: the statutory, customary and informal tenure systems. However, it was observed that these tenure systems were bedeviled by numerous issues and challenges such as tenure insecurity, conflicts/contestations among others which grossly affects agricultural productivity in the nation $[11,14]$. Hence, it was not surprising, that faced with these contrasting land tenure systems and the considerable hassle in getting land for public purposes especially in southern Nigeria, the military government sought to unify the two systems through the Land Use Decree of 1978 [12,15]. The thrust of the Decree was largely to extend the northern system of land management to the whole country as a means of ensuring easier access to land for government and providing remedy to the numerous challenges posed by the then existing tenure systems.

The aim of this paper is to examine the existing land tenure systems in Nigeria and how these systems impact on agricultural productivity in the country, using data drawn from an empirical study conducted in Gombe state. The availability of such data provided a unique opportunity to relate land tenure systems in Nigeria to agricultural productivity in the study area which is an aspect that experiences great dearth in literature. In this respect, the paper addresses the following key objectives: Identify and examine land tenure systems operational in Gombe state; identify and examine land tenure related factors influencing agricultural development in Gombe state and determine the relationship between land tenure systems and agricultural development in the study area. The paper is organized as follows: the Review of Related Literature section presents the review of the related literatures, the Methodology section presents the methodology adopted for the study, and Results and Discussion section presents results and discussion of data analyzed while the conclusion was presented in the last section.

\section{Review of Related literature}

Land tenure is the legal or customary relationship defined by individuals, groups, societies, communities or group of people with respect to land [16]. The rules related to land tenure defines how access to land is granted in respect of rights to use, rights to transfer or alienate, rights to control and rights to restrain others from use of such land [17]. Radoki [18] defines tenure in common law terms as 'a collection of rights, each of which is a relationship between persons and organizations as to land'. In the FAO [17] report it was noted that land tenure provides the following intersecting rights or interests on land: competing, overriding, complementary and overlapping web of land interests. Land tenure systems can be defined in terms of customs/traditions or by means of legal/statutory provisions of the law. In line with the aforementioned, Payne [5] classified land tenure systems into five categories i.e. public, private, religious, customary and informal land tenure systems. Antony [16] summarized these into: customary land tenure; statutory land tenure and informal land tenure. 
Mantebea Mends T, De Meijere J [19] asserted that prior to colonization of Sub-Saharan African countries, land was generally owned by the collective (community, clan, households, family etc). Individuals only have the rights of use of such land which cannot be sold to strangers outside the collective. Hence, the customary land tenure system, where the ownership of land was vested in the collective was the general practice [20]. However, during the colonial era, land ownership by individuals in form of freehold interest was introduced to allow the colonial state access land for their needs. Dabara et al. [21] noted that land ownership at this time was vested in the state; individuals were only allowed to have occupancy rights authorized by the state (freehold ownership under the statutory land tenure system). In line with the foregoing, Mabogunje [7] observed that within SubSaharan Africa 'private land ownership and the registration of individual property rights was largely an imported concept and is most common in urban areas where it was introduced or strengthened by the colonial administrators for the benefit of European settlers'. By the end of the colonial era, the indigenous customary land tenure system was operating simultaneously with European based tenure system in the rural and urban areas respectively. After independence, most of the Sub Sahara African countries including Nigeria still retained the dual tenure systems [7,22].

In Nigeria particularly, there is variation in land tenure systems practiced by communities. Fabiyi [11] attributed this difference to 'political experience and administrative policies of the past colonial masters'. Mabogunje [14] observed that these diverse land tenure systems can be categorized into two major groups. The first group was largely practiced in northern Nigeria (land being vested in the state authorities in line with the colonial disposition to tenure systems). The second group was majorly practiced in southern Nigeria (land being vested in the collective i.e. lineages, communities etc), the exception are lands acquired for public use. It was observed that this tenure system was bedeviled with myriad of challenges. These challenges include multiple sales of one land to more than one buyer leading to duplicity of ownership; fragmentation of lands; land speculation, land related conflicts/contestations among others. It was against this background that the Federal Military government promulgated the Land Use Act of 1978 to tackle these challenges [11]. Article 1 of the Act stated that "all lands comprised in the territory of each state in the federation are hereby vested in the military governor of the state". This Decree was enshrined in the 1979 Constitution and later in the 1999 Constitution of Nigeria. However, it was observed that since its promulgation over four decades ago, it has created a new set of problems and challenges for land use, management and control in Nigeria [11].

Nigeria to a great extend is an agrarian nation, Mathew [9] observed that over $56.8 \%$ of Nigeria's working force are grossly engaged in farming. The importance of the agricultural sector in contributing to the economic development of the nation cannot be overemphasized. The history of agricultural development in Nigeria is intricate and comprised divers agricultural programmes aimed at improving the sector [23]. Jibowo [24] asserted that the history of agricultural development in Nigeria can be divided into three. These are pre-colonial era, colonial era and post-colonial era. The pre-colonial era was mainly a period whereby improved varieties of crops and livestock where introduced in the country by the colonial masters. Throughout the colonial era the British made conscious efforts to improve agricultural productivity in the country. In the post-colonial era, the Nigerian government have initiated and executed quite a number of agricultural programs with a view to improving agricultural productivity. Such programs as identified by Jibowo [24] includes the 'National Accelerated Food Production Project (NAFPP) 1972, Agricultural Development Projects, (ADPs) 1975, the Accelerated Development Area Project (ADAP) 1982, and the Multi-state Agricultural Development Projects (MSADP) 1986, Operation Feed the Nation, (OFN) 1976, the River Basin Development Authority (RBDA) 1973, the Green Revolution Program (GRP) 1980, the Directorate of Foods Roads and Rural Infrastructure (DFRRI) 1986, the National Directorate of Employment (NDE) 1986, the Nigeria Agricultural Insurance Scheme (NAIS) 1987, the National Fadama Development Project (NFDP) 1992, the Poverty Alleviation Program (PAP) 2000, National Economic Empowerment and Development Strategy (NEEDS) 2004, and the National Special Program for Food Security (NSPFS) 2003 among others'. Ovwigho [25] observed that in spite of all the agricultural development programs implemented by the Nigerian government, much is still desired in realizing sustainable agricultural development and productivity in the country. This present study seeks to determine whether there is a relationship between the nation's existing land tenure systems and agricultural developing and productivity in a developing nation like Nigeria, drawing out empirical data from Gombe state. This is hoped to extend the frontier of knowledge in this field as this is one of the very few papers that looked at such correlations in developing economies.

\section{Methodology}

The study area is Gombe State (distinct from the capital city Gombe), it is one of the 36 states in Nigeria. The state is located in Northeastern region of the country. It was created by the then General Sani Abacha's administration in 1996. The state shares boundaries with Bauchi, Taraba, Borno, Yobe and Adamawa states. It is mainly an agrarian state with a land area of about 20,265 km². The state has two distinct seasons (rainy season which starts from April to October with an average rainfall of $850 \mathrm{~mm}$ and the dry season which starts around November to March). From the last population census conducted in Nigeria in 2006 it was recorded that the population of the state was around 2,365,000 people with a growth rate of an average of 2.60. Gombe is made up of three senatorial districts and Eleven Local Government Areas (LGA). Gombe South senatorial district comprised of the following LGA's: Kaltungo, Balanga, Shongom and Billiri; Gombe Central senatorial district comprised of Akko and Yamaltu Deba while Gombe North senatorial district comprised of Funakaye, Kwami, Gombe, Nafada and Dukku. 
The targeted population for the study comprised of 7,832 households in purposively selected agrarian settlements cutting across the 3 senatorial districts in the state. The population was stratified into three zones base on the senatorial districts and two locations were selected purposively from this stratification. From Gombe south, Tula and Billiri were selected; from Gombe North Dukku and Kwami were selected and from Gombe central Akko and Yamaltu Deba were selected. The sample size for the study comprised of 500 households in each of the study locations. Hence, 500 questionnaires were administered on the household heads of the 6 study locations making a total of 3,000 questionnaires (representing $38.3 \%$ of the targeted population). The random sampling technique was adopted in the questionnaire administration. The questionnaire was structured into three sections. Section 1 was designed to obtain data on the socio-economic characteristics of the respondents such as sex, education, family size etc. Section 2 was designed to obtain data on the existing land tenure systems practiced in the study area while section 3 was designed to obtain data on productivity level of selected common crops in the study area such as maize, beans, groundnut, rice and guinea corn. This was achieved by means of budgetary analysis from the last farming season in 2018. Similarly, data on the factors influencing agricultural productivity in the study area was also obtained in this section. Descriptive statistical tools such as frequency counts, averages, weighted mean and percentages were used in analyzing the data obtained. The Relative Importance Index (RII) was used to identify and rank the variables. Inferential statistical tool such as multiple regressions were also used in analyzing the relationship between the criterion or dependent variable (land tenure systems) and the predictors or independent variables (agricultural productivity of the selected crops in the selected locations).

The Relative Importance Index (RII) is presented as

$\mathrm{RII}=\frac{\sum \mathrm{W}}{\mathrm{A} * \mathrm{~N}}=\frac{5 \mathrm{n}_{5}+4 \mathrm{n}_{4}+3 \mathrm{n}_{3}+2 \mathrm{n}_{2}+\mathrm{n}_{1}}{5 \mathrm{~N}}$

Where:

$\mathrm{W}=$ weighting given to each statement by the respondents and ranges from 1 to 5 ;

$\mathrm{n}_{5}=$ strongly agreed; $\mathrm{n}_{4}=$ agreed; $\mathrm{n}_{3}=$ uncertain; $\mathrm{n}_{2}=$ disagreed; $\mathrm{n}_{1}=$ strongly disagreed

$A=$ Higher response integer (5); and

$\mathrm{N}=$ Total number of respondents.

The regression equation adopted is presented as

$Y=a+b_{1} A P T U+b_{2} A P B I+b_{3} A P D U+b_{4} A P K W+b_{5} A P A K+b_{6} A P Y A$

Where:

$\mathrm{Y}=$ Land Tenure Systems (LTS)

APTU=Agricultural productivity in Tula $\left(X_{1}\right)$

$\mathrm{APBI}=$ Agricultural productivity in Billiri $\left(\mathrm{X}_{2}\right)$

APDU = Agricultural productivity in Dukku $\left(X_{3}\right)$

APKW=Agricultural productivity in Kwame $\left(X_{4}\right)$

APAK=Agricultural productivity in Akko $\left(X_{5}\right)$

APYA $=$ Agricultural productivity in Yamaltu Deba $\left(X_{6}\right)$

$b_{1}, b_{2} \ldots . . . . . b n$ are multiple regression coefficients for the independent variables

"a" is an error term which points to the fact that a proportion of the variance in the dependent variable $Y$ is unexplained by the regression equation.

\section{Results and Discussion}

This section presents and discusses the results obtained from analysis of data collated from the study. Table 1 presents the respondents profile in respect of their socio-economic characteristics. The study area covers the three senatorial districts of the state (two Local Government Areas from each senatorial district were purposively selected). The selected study locations for Gombe South senatorial district are Tula and Billiri; Dukku and Kwame are selected from the North Central senatorial district; while Akko and Yamaltu Deba were selected from Gombe central Senatorial district. To obtain data from the respondents 500 questionnaires were administered on farm household heads in the study locations, making a total of 3,000 questionnaires distributed. However only $2,223(74.1 \%)$ questionnaires were correctly filled and returned for analysis. 432(86.4\%) questionnaire were obtained from Tula, 389(77.8\%) from Billiri, 298(58.6\%) from Dukku, $371(72.4 \%)$ from Kwame, 316(63.2\%) from Akko and 417(83.4\%) from Yamaltu Deba.

Table 1. Respondents' profile.

\begin{tabular}{|c|c|c|c|c|c|c|c|c|}
\hline & & Tula & Billiri & Dukku & kwame & Akko & Yamaltu Deba & Mean \\
\hline \multirow[t]{4}{*}{ Gender } & Male & $387(89.6)$ & 309 (79.2) & $279(93.6)$ & $356(96)$ & $287(90.8)$ & $374(89.7)$ & 1992(89.6) \\
\hline & Female & $45(10.4)$ & $80(20.8)$ & $19(6.4)$ & $15(4.0)$ & $29(9.2)$ & $43(10.3)$ & $231(10.4)$ \\
\hline & below 30 & $5(1.2)$ & $6(1.5)$ & $2(0.7)$ & $11(3.0)$ & $18(5.7)$ & $6(1.4)$ & $48(2.2)$ \\
\hline & $31-40$ & $72(16.7)$ & $8(2.1)$ & $5(1.7)$ & $22(6.0)$ & $13(4.1)$ & $17(4.1)$ & $137(6.2)$ \\
\hline \multirow[t]{4}{*}{ Age } & $41-50$ & $71(16.4)$ & $82(21.1)$ & $187(62.7)$ & $48(13.0)$ & $67(21.2)$ & $84(20.1)$ & $539(24.2)$ \\
\hline & $51-60$ & $275(63.7)$ & $281(72.2)$ & 103 (34.6) & $281(75.6)$ & $198(62.7)$ & 301 (72.2) & $1439(64.7)$ \\
\hline & above 60 & $9(2.1)$ & $12(3.1)$ & $1(0.3)$ & $9(2.4)$ & $20(6.3)$ & $9(2.2)$ & $60(2.7)$ \\
\hline & Married & $412(95.4)$ & $359(93.3)$ & $289(97.0)$ & $365(98.4)$ & $287(90.8)$ & $389(93.3)$ & 2101(94.5) \\
\hline \multirow[t]{5}{*}{ Marital status } & Single & $1(0.2)$ & $10(2.6)$ & $9(3.0)$ & $6(1.6)$ & $13(4.2)$ & $11(2.6)$ & $50(2.2)$ \\
\hline & widow/widower & $16(3.7)$ & $16(4.1)$ & $0(0)$ & $0(0)$ & $15(4.7)$ & $13(3.1)$ & $60(2.7)$ \\
\hline & divorced & $3(0.7)$ & $4(1.0)$ & $0(0)$ & $0(0)$ & $1(0.3)$ & $4(1.0)$ & $12(0.4)$ \\
\hline & $1-4$ & $7(1.6)$ & $21(5.4)$ & $5(1.7)$ & $14(3.8)$ & $87(27.5)$ & $27(6.5)$ & $161(7.2)$ \\
\hline & 5- 9 & $332(76.9)$ & $170(43.7)$ & $6(2.0)$ & $16(4.3)$ & $85(26.9)$ & $209(50.1)$ & $818(36.8)$ \\
\hline \multirow[t]{6}{*}{ Family size } & $10-14$ & $73(16.9)$ & $139(35.7)$ & $130(43.6)$ & $201(54.2)$ & $116(36.7)$ & $129(30.9)$ & $788(35.4)$ \\
\hline & $15-19$ & $14(3.2)$ & $51(13.1)$ & $128(43.0)$ & $102(27.5)$ & $16(5.1)$ & $33(7.9)$ & $344(15.5)$ \\
\hline & above 19 & $6(1.4)$ & $8(2.1)$ & $29(9.70$ & $38(10.2)$ & $12(3.8)$ & $19(4.6)$ & $112(5.0)$ \\
\hline & None & $170(39.4)$ & $142(36.5)$ & $187(62.7)$ & $209(56.3)$ & $121(38.3)$ & $162(38.8)$ & 991(44.6) \\
\hline & Primary Certificate & $107(24.7)$ & $118(30.3)$ & $75(25.2)$ & $74(19.9)$ & $109(34.5)$ & $113(27.2)$ & $596(26.8)$ \\
\hline & Secondary certificate & $88(20.4)$ & $67(17.3)$ & $34(11.4)$ & $85(23.0)$ & $78(24.7)$ & $69(16.5)$ & $421(18.9)$ \\
\hline
\end{tabular}




\begin{tabular}{|l|l|c|c|c|c|c|c|c|}
\hline & & Tula & Billiri & Dukku & kwame & Akko & Yamaltu Deba & Mean \\
\hline Educational qualification & ND/NCE & $39(9.0)$ & $41(10.5)$ & $2(0.7)$ & $3(0.8)$ & $6(1.9)$ & $42(10.1)$ & $133(6.0)$ \\
\hline & HND/B.Sc & $28(6.5)$ & $21(5.4)$ & $0(0)$ & $0(0)$ & $2(0.6)$ & $31(7.4)$ & $82(3.7)$ \\
\hline & M.Sc & $0(0)$ & $0(0)$ & $0(0)$ & $0(0)$ & $0(0)$ & $0(0)$ & $0(0)$ \\
\hline & PhD & $0(0)$ & $0(0)$ & $0(0)$ & $0(0)$ & $0(0)$ & $0(0)$ & $0(0)$ \\
\hline & Under 5 years & $5(1.2)$ & $7(1.8)$ & $0(0)$ & $2(0.5)$ & $7(2.2)$ & $4(1.0)$ & $25(1.1)$ \\
\hline & $6-10$ years & $3(0.7)$ & $17(4.4)$ & $21(7.0)$ & $78(21.0)$ & $27(8.5)$ & $18(4.3)$ & $164(7.4)$ \\
\hline Years of experience & $11-15$ years & $31(7.2)$ & $59(15.2)$ & $74(24.8)$ & $26(7.0)$ & $59(18.7)$ & $49(11.8)$ & $298(13.4)$ \\
\hline & $16-20$ & $71(16.4)$ & $104(26.7)$ & $92(30.9)$ & $107(88.9)$ & $102(32.3)$ & $107(25.7)$ & $583(26.2)$ \\
\hline & above 20 years & $322(74.5)$ & $202(51.9)$ & $111(37.2)$ & $158(42.6)$ & $121(38.3)$ & $239(57.3)$ & $1153(51.9)$ \\
\hline
\end{tabular}

Source: Field survey, 2019.

Table 1 presents respondents' profile in terms of their socio-economic characteristics. $89.6 \%$ of the respondents are of the male gender; while $10.4 \%$ are of the female gender. Most of the respondents are between the ages 51 to 60 years (64.7\%). $94.5 \%$ of the respondents are married and most of them (36.8\%) have family sizes of between 5 and 9 persons. Apparently $44.6 \%$ of the respondents are illiterates while the others are educated with different level of certification. All the respondents have experience in farming, with most of them (51.9\%) having farming experience of over 20 years.

There are majorly three types of land tenure systems subscribed to in the study area. These comprise of statutory, customary and informal systems (this is congruent with what was obtainable in other parts of the country $[8,11,26]$. Table 2 showed that customary land tenure system is the most subscribed in the study area with a mean of $60.1 \%$. This is followed by informal land tenure system (with a mean of 20.6\%) and lastly the statutory land tenure system (with a mean of 19.3\%). For the statutory LTS, the highest subscription was seen in Akko (43.4\%), this could be connected to the fact that Akko is very close to the capital city of the state. Hence, land buyers most often prefer to have the statutory certificate of occupancy signed by the state governor. This mitigates litigation and ownership conflicts which are common in city centers and its outskirts in developing economies. Kwame had the highest subscription to customary LTS in the study area $(71.2 \%)$, while Akko had the least $(44.9 \%)$. As for the informal LTS, Tula had the highest (32.2\%) while Kwame had the least (9.1\%). This implies that the customary LTS is still predominant in the study area. Hence, customs and traditions related to land ownership such as non-alienation of land to strangers among others are still being practiced in the study area. This finding is not peculiar to the study area as studies from other developing economies such as Fisher [6] and Mabike, Musinguzi, Antonio and Sylla [27] showed similar results. However, in developed economies the situation is different as the statutory LTS is widely practiced [5].

Table 2. Land tenure systems in the study area.

\begin{tabular}{|l|c|c|c|c|c|c|c|}
\hline Land tenure systems subscribed & Tula & Billiri & Dukku & Kwame & Akko & Yamaltu Deba & Mean \\
\hline Statutory & $27(6.2)$ & $57(14.7)$ & $56(18.8)$ & $73(19.7)$ & $137(43.4)$ & $79(18.9)$ & $429(19.3)$ \\
\hline Customary & $266(61.6)$ & $229(58.9)$ & $201(67.5)$ & $264(71.2)$ & $142(44.9)$ & $233(55.9)$ & $1335(60.1)$ \\
\hline Informal & $139(32.2)$ & $103(26.4)$ & $41(13.7)$ & $34(9.1)$ & $37(11.7)$ & $105(25.2)$ & $459(20.6)$ \\
\hline Total & $432(100)$ & $389(100)$ & $298(100)$ & $371(100)$ & $316(100)$ & $417(100)$ & $2223(100)$ \\
\hline
\end{tabular}

Source: field survey, 2019.

Note: the figures in parenthesis are in percentage.

Investigation as to how land was acquired/accessed or obtained by the respondents revealed that land inheritance is the predominant means of acquisition/access to land by the respondents (38.8\%). This is not surprising because the study areas with the exception of a large part of Akko are all situated/located in farming settlements were land ownership is handed over from generation to generation by means of inheritance. This is followed by purchase (21.8\%), then lease (20.4\%), then squatting (11.1\%) and gift (7.9\%). The variation between the selected study areas shows that access by inheritance was highest in Tula (59.5\%) and lowest in Akko (18.7\%). Land acquired through purchase was highest in Akko (46.5\%) and lowest in Tula (11.3\%). This could be connected to the fact that Tula (a purely farming settlement) is located far from the capital city of the state (about 80 kilometers) while Akko has merged with the capital city (you hardly can differentiate between the two) most especially Tunfure town in Akko, which is less than a kilometer from Gombe capital city. Land obtained through gift was highest in Dukku (9.1\%) and least in Tula (5.3\%). Land acquired through leasing was highest in Yamaltu Deba (26.9\%) and least in Dukku (13.7\%). Land obtain by means of squatting was highest in Yamaltu Deba (18.9\%) and least in Akko (4.1\%). The implication of this is that family heads as custodians of family lands must ensure that the lands are being held in trust for the future generations as well as ensure that the said land remains in the family. Hence the tradition that women cannot inherit land so as not to transfer ownership to their spouse's family. The nonalienation of land tradition explains why most of the respondents (38.8\%) got their land through inheritance (Table 3). This finding disagrees with a similar study conducted in Uganda which found that land acquisition is mostly through buying/purchase [27]. 
Table 3. Land acquisition by respondents in the study area.

\begin{tabular}{|l|c|c|c|c|c|c|c|}
\hline How land was acquired & Tula & Billiri & Dukku & kwame & Akko & Yamaltu Deba & Mean \\
\hline Inheritance & $257(59.5)$ & $126(32.4)$ & $139(46.5)$ & $154(41.5)$ & $59(18.7)$ & $127(30.5)$ & $862(38.8)$ \\
\hline Purchase & $49(11.3)$ & $68(17.5)$ & $79(26.5)$ & $79(21.3)$ & $147(46.5)$ & $63(15.1)$ & $485(21.8)$ \\
\hline Gift & $23(5.3)$ & $35(9)$ & $27(9.1)$ & $27(7.4)$ & $28(8.9)$ & $36(8.6)$ & $176(7.9)$ \\
\hline Lease & $61(14.2)$ & $103(26.4)$ & $41(13.7)$ & $68(18.3)$ & $69(21.8)$ & $112(26.9)$ & $454(20.4)$ \\
\hline Squatting & $42(9.7)$ & $57(14.7)$ & $12(4.2)$ & $43(11.5)$ & $13(4.1)$ & $79(18.9)$ & $246(11.1)$ \\
\hline Total & $432(100)$ & $389(100)$ & $298(100)$ & $371(100)$ & $316(100)$ & $417(100)$ & $2223(100)$ \\
\hline
\end{tabular}

Source: Field Survey, 2019.

The degree of security of land rights as well as land tenure security was observed from the point of view of documentary evidence of land rights possessed by the respondents. Surprisingly $34.1 \%$ percent of the respondents do not have any documentary evidence in form of certificate of occupancy, lease agreement, sale agreement, letter of administration etc. This could not be unconnected to the fact that most of the respondents inherited their lands from their family lineage. And since the lands were majorly in farming settlements were almost everyone knows each other and which land belongs to which family. The issue of contestation over land is minimal hence, the sense of tenure security without recourse to documentary evidence. Only $15.4 \%$ of the respondents have legal title deed/certificate of occupancy. Akko has the highest number of respondents with title deed/certificate of occupancy (25\%) while Dukku has the least (10.4\%). $21.4 \%$ of the respondents have purchase agreement as documentary evidence backing their ownership of land in the study area. Variations among the selected study locations revealed that Dukku had the highest number of respondents with purchase agreement (29.9\%) while Yamaltu Deba had the least (19.4\%). As regards will/letter of administration as documentary evidence of land ownership, the study showed that $7.4 \%$ of the respondents possess such document. It was also revealed that $21.7 \%$ of the respondents have lease agreement as documentary evidence for land ownership. The inability of the greater percentage of the respondents to have documentary evidence of ownership could pose a threat to the security of such land. Most especially if there is any conflict or contestation over the ownership of such lands. In developed economies, possession of documentary evidence for land ownership is taken more seriously than in developing economies like Nigeria (Table 4).

Table 4. Documentary evidence of land ownership in the study area.

\begin{tabular}{|l|c|c|c|c|c|c|c|}
\hline Documentary evidence & Tula & Billiri & Dukku & kwame & Akko & Yamaltu Deba & Mean \\
\hline $\begin{array}{l}\text { Title deed/certificate of occu- } \\
\text { pancy }\end{array}$ & $49(11.3)$ & $74(19)$ & $31(10.4)$ & $41(11.1)$ & $79(25)$ & $68(16.3)$ & $342(15.4)$ \\
\hline Purchase agreement & $87(20.1)$ & $98(25.2)$ & $89(29.9)$ & $73(19.7)$ & $48(15.2)$ & $81(19.4)$ & $476(21.4)$ \\
\hline Will/letter of administration & $39(9.0)$ & $43(11.1)$ & $16(5.4)$ & $12(3.2)$ & $32(10.1)$ & $23(5.5)$ & $165(7.4)$ \\
\hline Lease agreement & $103(23.8)$ & $76(19.5)$ & $71(23.8)$ & $96(25.9)$ & $48(15.2)$ & $89(21.3)$ & $483(21.7)$ \\
\hline No documentary evidence & $154(35.8)$ & $98(25.2)$ & $91(30.5)$ & $149(40.1)$ & $109(34.5)$ & $156(37.5)$ & $1466(34.1)$ \\
\hline Total & $432(100)$ & $389(100)$ & $298(100)$ & $371(100)$ & $316(100)$ & $417(100)$ & $2223(100)$ \\
\hline
\end{tabular}

Source: Field Survey, 2019

Table 5 shows the budgetary analysis for the production of rice, beans, groundnut, maize and guinea corn in the study area. The aforementioned crops are the common crop types cultivated in the study area. The analysis in table 5 is an aggregate of data obtained from Tula, Billiri, Dukku, Kwame, Akko and Yamaltu Deba. The data obtained was for the farming season in the year 2018. The results showed that the average gross revenue obtained for the selected crop types per acre are as follows: rice was $\$ 873,800(\$ 2,427)$; bean was $\# 654,890$ (\$1,819), groundnut was $\$ 737,822(\$ 2,050)$, maize was $\$ 600,788(\$ 1,669)$ and guinea corn was $\$ 576,220(\$ 1,601)$. Rice was observed to have the highest revenue generated. This is perhaps due to its high demand, acceptability and consumption rate nationwide (in Nigeria hardly will a family stay a day without eating rice). The average variable costs incurred in the production of the selected crops are as follows: rice was \$312,132 (\$867), beans was \#204,757 (\$569), groundnut was $\$ 210,680$ ( $\$ 585)$, maize was $\# 200,256$ ( $\$ 556$ )

and guinea corn was $\$ 190,865$ ( $\$ 530)$. The cultivation of rice was observed to be more cumbersome and difficult as it is cultivated on marshy or water log land. Hence it involves spending more in terms of finance, than other selected crops in its production. Guinea corn was observed to have the least variable cost incurred, this could be due to the fact that plowing, and weeding and harvesting of guinea corn is much easier than the other selected crop types. The Net income for rice which is $\$ 476,668$ (\$1,342) was the highest perhaps due to its high demand as mentioned earlier, while the least net income was recorded for guinea corn which is $\# 311,822$ (\$866) this could also be due to the fact that demand and consumption of guinea corn is more or less restricted to the Northern part of the country. The implication of this finding is that the production of rice which is widely accepted in all part of the country and has high demand should be a priority for farmers so as to generate more revenue from its production. 
Table 5. Budgetary analysis of selected farm products produced on an acre of land in the study area.

\begin{tabular}{|c|c|c|c|c|c|}
\hline Item & Rice & Beans & Groundnut & Maize & Guinea corn \\
\hline (A)Gross revenue & $873,800(2,427)$ & $654,890(1,819)$ & $737,822(2,050)$ & $600,788(1,669)$ & $576,220(1,601)$ \\
\hline \multicolumn{6}{|l|}{ (B) Variable cost } \\
\hline land clearing & $27,880(77)$ & $16,700(46)$ & $16,000(44)$ & $17,400(48)$ & $16,700(46)$ \\
\hline harrowing/tilling/ridging & $67,100(186)$ & 47,399 (132) & $41,500(115)$ & $39,200(109)$ & $38,100(106)$ \\
\hline Planting & $16,870(47)$ & $12,081(34)$ & $13,970(39)$ & $12,900(36)$ & $10,775(30)$ \\
\hline Weeding & $79,382(220)$ & $51,900(144)$ & $47,000(131)$ & $41,333(115)$ & $50,390(140)$ \\
\hline Harvesting & $47,000(131)$ & $29,877(83)$ & $33,540(93)$ & $25,880(72)$ & $31,400(87)$ \\
\hline Fertilizer & $58,000(161)$ & $33,800(94)$ & $45,770(127)$ & $48,500(135)$ & $29,300(81)$ \\
\hline Transportation & $15,900(44)$ & $13,000(36)$ & $12,900(36)$ & $15,043(42)$ & $14,200(39)$ \\
\hline Total variable cost & $312,132(867)$ & $204,757(569)$ & $210,680(585)$ & $200,256(556)$ & $190,865(530)$ \\
\hline (C) Total fixed cost (rent) & $85,000(236)$ & $73,700(205)$ & $71,200(198)$ & 69,988 (194) & $73,533(204)$ \\
\hline (D) Total cost $(B+C)$ & $397,132(1,103)$ & $278,457(774)$ & $281,880(783)$ & $270,244(751)$ & $264,398(734)$ \\
\hline Net farm income (A-D) & $476,668(1,324)$ & $376,433(1,046)$ & $455,942(1,267)$ & $330,544(918)$ & $311,822(866)$ \\
\hline
\end{tabular}

Source: Field Survey, 2019.

Note: the figures in parenthesis are the US Dollar equivalent at $\$ 1=\$ 360$ as at the time of writing this report.

Table 6 presents factors influencing agricultural productivity in Gombe which was used in the analysis of the Relative Importance Index (RII) of the said factors (see Table 7). Among the aforementioned factors, land tenure insecurity ranked first (with RII of 0.933963 ) as a factor that influences agricultural productivity in the study area. This implies that the more secured in terms of tenure a land is, there is likelihood of higher productivity. In the same vein when there is land tenure insecurity, the farmer may not put their best in development of the said land which could translate to lower productivity. The second ranked factor was land tenure and poverty issues/challenges (with RII of 0.897616). It is obvious that mechanized agriculture/commercial agriculture involves a lot of money. The more money a farmer has to invest in his farm, the more likely for the farmer to have higher productivity.
However, in the study area most of the farmers are handicapped due to prevalent poverty among the farmers in the study area. Other factors in order of their ranking includes: political/bureaucratic bottlenecks in land acquisition (RII 0.846154); Environmental issues/challenges (RII 0.826631); Education issues/challenges (RII 0.804049); Land tenure and food security issues/challenges (RII 0.786865 ); Tenure rules as stipulated in the Land Use Act (LUA), land conflict issues/ challenges (RII 0.65596) and Gender issues/challenges (RII 0.585425). The factor that ranked the least was management issues/challenges (RII 0.548538). This finding implies that for farmers particularly in the study area and generally in similar developing economies to obtain high agricultural productivity, they need to address the issue of land tenure security, poverty, land conflicts and education among others.

Table 6. Factors influencing agricultural productivity in Gombe.

\begin{tabular}{|l|c|c|c|c|c|}
\hline Factors & Strongly Agreed & Agreed & Undecided & Disagreed & Strongly Disagreed \\
\hline Tenure rules as stipulated in LUA & $256(11.5)$ & $1,125(50.6)$ & $217(9.8)$ & $328(14.7)$ & $297(13.4)$ \\
\hline Land tenure and food security issues/challenges & $983(44.2)$ & $590(26.5)$ & $324(14.6)$ & $173(7.8)$ & $153(6.9)$ \\
\hline political/bureaucratic bottlenecks in land acquisition & $993(44.7)$ & $1009(45.4)$ & $59(2.7)$ & $65(2.8)$ & $97(4.4)$ \\
\hline Environmental issues/challenges & $794(35.7)$ & $981(44.1)$ & $423(19.1)$ & $0(0)$ & $25(1.1)$ \\
\hline Gender issues/challenges & $324(14.6)$ & $591(26.6)$ & $116(5.2)$ & $983(44.2)$ & $209(9.4)$ \\
\hline Land conflict issues/challenges & $217(9.8)$ & $1100(49.5)$ & $53(2.3)$ & $794(35.7)$ & $59(2.7)$ \\
\hline $\begin{array}{l}\text { Common property resource management issues/ } \\
\text { challenges }\end{array}$ & $429(19.3)$ & $185(8.3)$ & $297(13.4)$ & $1009(45.4)$ & $303(13.6)$ \\
\hline Land tenure and poverty issues/challenges & $1541(69.3)$ & $468(21.1)$ & $0(0)$ & $186(8.4)$ & $28(1.2)$ \\
\hline land tenure insecurity & $340(15.3)$ & $852(38.3)$ & $1573(29.2)$ & $173(7.8)$ & $208(9.4)$ \\
\hline Education issues/challenges & $1094(49.2)$ & $641(28.8)$ & $103(4.7)$ & $209(9.4)$ & $176(7.9)$ \\
\hline
\end{tabular}

Source: Field Survey, 2019

Table 7. Relative Importance Index (RII) of factors influencing agricultural development in Gombe.

\begin{tabular}{|l|c|c|c|c|c|c|c|c|}
\hline Factors & 5 & 4 & 3 & 2 & 1 & $\sum \mathrm{w}$ & RII & Rank \\
\hline Tenure rules as stipulated in LUA & 256 & 1,125 & 217 & 328 & 297 & 7384 & 0.664327 & 7 \\
\hline Land tenure and food security issues/challenges & 983 & 590 & 324 & 173 & 153 & 8746 & 0.786865 & 6 \\
\hline political/bureaucratic bottlenecks in land acquisition & 993 & 1009 & 59 & 65 & 97 & 9405 & 0.846154 & 3 \\
\hline Environmental issues/challenges & 794 & 981 & 423 & 0 & 25 & 9188 & 0.826631 & 4 \\
\hline Gender issues/challenges & 324 & 591 & 116 & 983 & 209 & 6507 & 0.585425 & 9 \\
\hline Land conflict issues/challenges & 217 & 1100 & 53 & 794 & 59 & 7291 & 0.65596 & 8 \\
\hline Common property resource management issues/challenges & 429 & 185 & 297 & 1009 & 303 & 6097 & 0.548538 & 10 \\
\hline Land tenure and poverty issues/challenges & 1541 & 468 & 0 & 186 & 28 & 9977 & 0.897616 & 2 \\
\hline land tenure insecurity & 340 & 852 & 1573 & 173 & 208 & 10381 & 0.933963 & 1 \\
\hline Education issues/challenges & 1094 & 641 & 103 & 209 & 176 & 8937 & 0.804049 & 5 \\
\hline Mean & & & & & & 8391.3 & 0.754953 & \\
\hline
\end{tabular}

Source: Analysis of Survey data, 2019. 
Tables 8 to 10 presents the regression analysis of land tenure systems and agricultural productivity in the selected study locations.

Table 8 showed the regression model summary result obtained from analysis of data for this study. It reveals a high positive correlation of 0.809 between all the variables. Table 9 tests the overall significance of the coefficients ( $\left.\beta^{\prime} s\right)$. The results obtained showed that the overall model is statistically significant, $[F(5,2217)=203.857, P=0.000]$. Table 10 presents the coefficients, the Enter Method was employed in the analysis (this will cause all predictors to be included in the output). From the significance values of the individual $\beta$ 's, results showed that all the predictors significantly predict agricultural productivity in the selected study locations. These include: agricultural productivity in Tula, Billiri, Dukku, Kwame, Akko and Yamaltu Deba, with $t=14.15, p=0.000<0.01 ; t=-0.322, p=0.027<0.05$; $t=7.422, \quad p=0.018<0.05 ; \quad t=0.662, \quad p=0.000<0.01 ; \quad t=2.541$ ， $p=0.045<0.05$ and $t=0.799, p=0.000<0.01$ respectively. Hence, it can be inferred that they are all statistically significant (note that 0.05 and 0.01 above indicates the significance levels at $5 \%$ and $10 \%$ respectively). The above analysis could be interpreted to mean that there is a strong significant positive relationship between land tenure systems and agricultural productivity in the study locations. The results reveal that land tenure systems affects agricultural productivity more in Tula (0.000), Kwame $(0.000)$ and Yamaltu Deba (0.000). This was followed by Dukku (0.018), then Billiri (0.027) and lastly Akko (0.045). This implies that there is a strong positive relationship between land tenure system and agricultural productivity in the study area. This finding is congruent with the ECA [4] and FAO [17] reports; as well as earlier studies conducted by Holden and Ghebru [1], Fabiyi [11] and Mabikke, et al. [27].

Table 8. Model Summary.

\begin{tabular}{|c|c|c|c|c|}
\hline Model & R & R Square & Adjusted R Square & Std. Error of the Estimate \\
\hline & 0.809 & 0.654 & 0.65 & 0.447 \\
\hline
\end{tabular}

a. Predictors: (Constant), Agricultural productivity in Tula, Billiri, Dukku, Kwame, Akko, Yamaltu Deba.

Table 9. Analysis of Variance (ANOVA).

\begin{tabular}{|l|c|c|c|c|c|}
\hline Model & Sum of Squares & df & Mean Square & F & Sig. \\
\hline Regression & 40.671 & 5 & 40.671 & 203.857 & .000 \\
\hline Residual & 21.547 & 2217 & 0.2 & & \\
\hline Total & 62.218 & 2222 & & & \\
\hline
\end{tabular}

a. Dependent Variable: Land Tenure Systems.

b. Predictors: (Constant), Agricultural productivity in Tula, Billiri, Dukku, Kwame, Akko, Yamaltu Deba.

Table 10. Coefficients.

\begin{tabular}{|l|c|c|c|c|c|}
\hline Mode & \multicolumn{2}{|c|}{$\begin{array}{c}\text { Unstandardized } \\
\text { Coefficients }\end{array}$} & $\begin{array}{c}\text { Standardized } \\
\text { Coefficients }\end{array}$ & $\mathrm{t}$ & Sig. \\
\hline & $\mathrm{B}$ & $\begin{array}{c}\text { Std. } \\
\text { Error }\end{array}$ & Beta & & \\
\hline (Constant) & 0.914 & 0.112 & & 8.172 & 0 \\
\hline Agricultural productivity Tula & 0.517 & 0.037 & 0.807 & 14.15 & 0 \\
\hline Agricultural productivity Billiri & -0.012 & 0.037 & -0.018 & -0.322 & 0.027 \\
\hline Agricultural productivity Dukku & 310 & 0.42 & 0.584 & 7.422 & 0.018 \\
\hline Agricultural productivity Kwame & 0.033 & 0.49 & 0.052 & 0.662 & 0 \\
\hline Agricultural productivity Akko & 13.007 & 5.255 & 0.734 & 2.541 & 0.045 \\
\hline $\begin{array}{l}\text { Agricultural productivity } \\
\text { Yamaltu Deba }\end{array}$ & -6.6654 & 8.398 & -0.24 & -0.799 & 0 \\
\hline
\end{tabular}

a dependent variable: Land Tenure System

\section{Conclusion}

The study examined the relationship between land tenure systems and agricultural productivity in Gombe state Nigeria. The study revealed that customary land tenure system is the predominant type of tenure system in the study area (with a mean value showing that $60.1 \%$ of the respondents are practicing this type of tenure system). This finding is not peculiar to the study area as studies from other developing economies such as Chimhowu [3] and Mabike, et al. [27] showed similar results. However, in developed economies the situation is different as the statutory LTS is seen to be widely practiced [5]. The study also showed that rice cultivation provided the highest net income generated when compared to other common crops cultivated in the study area (cultivation on an acre of land provided net income of about $\$ 873,800$ i.e. $\$ 2,427$ in the 2018 farming season). The study further showed that there is a strong positive relationship of 0.809 between land tenure systems and agricultural productivity in the study area. This finding is congruent with what was found in literature, studies such as Holden and Ghebru [1], Fabiyi [11] and Dabara et al. [22] showed similar results. The implication of this study for especially developing economies like Nigeria is that for better agricultural productivity, farmers need to have secured land tenures as this encourages investments in the secured land which consequently translates to improved agricultural productivity. It was recommended that the Nigerian government look into the existing land tenure systems as stipulated in the Nigerian Land Use Act (LUA) of 1978 with a view to reviewing same to address the inherent issues/challenges associated with the LUA. This will consequently impact on agricultural development and productivity in the country. This study is limited by its geographical coverage (i.e. just covering one state in Nigeria). Future studies could look at a wider range of geographical coverage in Nigeria as well as comparative analysis between countries in developing nations or both developing and developed nations.

\section{Acknowledgment}

The authors wish to acknowledge Nigerian Tertiary Education Trust Fund (TET Fund) for sponsoring this research work.

\section{References}

1. Holden ST, Ghebru H. Land tenure reforms, tenure security and food security in poor agrarian economies: Causal linkages and research gaps. Glob Food Sec. 2016; 10(16): 21-28. doi: 10.1016/j.gfs.2016.07.002

2. Olayiwola LM, Adeleye O. Land Reform - Experience from Nigeria. Promoting Land Administration and Good Governance 5th FIG Regional Conference Accra, Ghana. 2006: 8-11.

3. Chimhowu A. The 'new' African customary land tenure: Characteristics, features and policy implications of a new paradigm. Land Use Policy. 2019; 81: 897-903. doi: 10.1016/j.landusepol.2018.04.014

4. ECA. Land Tenure Systems and their Impacts on Food Security and Sustainable Development in Africa. Economic Commission for Africa. 2004: 54-67. 
5. Payne G. Urban Land Tenure Policy: Titles or Rights? Habitat Int. 2001; 25(3): 415-429. doi: 10.1016/S0197-3975(01)00014-5

6. Fisher R. Tensions and Tenures in Post-Apartheid South Africa. December 1993 International Land Tenure Conference. Royal Institute of Chartered Surveyors and the University of East London. 1993; 34-51.

7. Mabogunje AL. Perspective on Urban Land and Urban Management Policies in Sub-Saharan Africa. The World Bank. 1992; 47-63.

8. Lund C. African land tenure: Questioning basic assumptions. 2009; 45-59.

9. Uwakonye MN, Osho GS. An Econometric Analysis of Two Possible Land Reform Strategies in Nigeria. Journal of Business \& Economic Research. 2007; 5(3): 45-71. doi: 10.19030/jber.v5i3.2530

10. Dabara DI, Anthony A, Guyimu J, Oladimeji E, Oyediran O. Infrastructure Financing and Urban Development in Nigeria. Conference of the International Journal of Arts \& Sciences. 2015; 8(1): 79-86. doi: 10.2139/ ssrn. 2784497

11. Fabiyi LY. Land tenure reform in Nigeria: Implications for agricultural development and problems of implementation. 2009; 33-51.

12. Ankeli IA, Dabara ID, Omotehinshe OJ, Tanimu M, Oladimeji ML. A Review of the Implication of Land Use Act 1978 on Urban Land Use in Nigeria. The $12^{\text {th }}$ International Conference on Advances in Science, Humanities and Education, Shongai Centre, Porto Novo, Republic of Benin. 2017; 12(4): 141-146.

13. Alabi JK, Okunola AS, Dabara, ID, Odewande AG. Principles of Property Development and Management. $1^{\text {st }}$ edition. Ibadan, Aseda Publishing. 2012.

14. Mabogunje AL. Land Reform in Nigeria: Progress, Problems \& Prospects. 2009.

15. Udo RK. Land Use Policy and Land Ownership in Nigeria, Lagos, Ebieakwa Ventures. 1990.

16. Antony OL. Land Tenure Management Systems in Informal Settlements: A case study of Nairobi. A thesis submitted to the International Institute for Geo-information Science and Earth Observation (ITC) in partial fulfillment of the requirements for the degree of Master of Science in Geoinformation Management. 2005.
17. FAO. Land Tenure and Rural Development. Food and Agriculture Organization of the United Nations. 2002.

18. Radoki C. Politics and Performance: The implications of Emerging Governance Arrangements for urban Management Approaches and Information Systems. Habitat Int. 2003; 27(4): 523-547. doi: 10.1016/ S0197-3975(03)00004-3

19. Mantebea Mends T, De Meijere J. A Study of the Institution of the Customary Land Tenure System in the Supply of Property Rights for Urban Development-An Example of Accra, Ghana. Promoting Land Administration and Good Governance 5th FIG Regional Conference Accra, Ghana, 2006.

20. Anthony A, Dabara DI, Oni SS, Agidi O, Oladimeji E. Urbanization Dynamics and Land Use Pattern in Birnin Kebbi, Nigeria. Conference of the International Journal of Arts \& Sciences. 2015; 8(1): 41-52.

21. Payne G. Land, rights and innovation: Improving tenure security for the urban poor. ITDG. 2002.

22. Dabara DI, Ankeli IA, Akinjogbin OI, Omotehinshe JO, Omoyosi GA. A study of the legislations affecting property rights in Gombe State, Nigeria. Humanities and Social Sciences Review. 2017; 6(2): 1-8.

23. Ishmael O. Agricultural Development Policies in Nigeria: A Critique. Jos Journal of Economics. 2002; 2(1): 48-60.

24. Jibowo A. History of Agricultural Extension in Nigeria. In: Adedoyin SF (ed). Agricultural Extension in Nigeria. Ilorin: Agricultural Extension Society of Nigeria. 2005: 1-12.

25. Ovwigho BO. Community Farm Extension Model for Agricultural Development in Nigeria. International Journal of Rural Studies. 2009; 16(1): 1-6.

26. Akinola AA, Adeyemo R. Effects of property rights on agricultural production: The Nigerian experience. Journal of Development and Agricultural Economics. 2013; 5(10): 382-389.

27. Mabikke S, Musinguzi M, Antonio D, Sylla O. Land tenure and its impacts on food security in Uganda: Empirical evidence from ten districts. Paper presented at the 2017 World Bank Conference on land and poverty in Washington DC. 2017. 